\section{Purple Nutsedge Management in Florida Strawberry with Herbicides and a Modified Florida 3-Way Fumigation Program}

\author{
Kshitij Khatri ${ }^{1}$, Natalia Peres ${ }^{1}$, Joseph Noling ${ }^{2}$, \\ and Nathan Boyd ${ }^{1}$
}

ADDITIONAL INDEX wORDs. Cyperus rotundus, drip irrigation, Fragaria ananassa, minicoulter, soil fumigation

Summary. The "Florida 3-way" consists of chloropicrin 35\%+1,3-dichloropropene $65 \%$ followed by minicoulter application of metam potassium. We evaluated the efficacy of a modified version of the Florida 3-way in which chloropicrin $35 \%+1,3$-dichloropropene $65 \%$ was used as primary bed fumigant and consisted of different drip tape application timings (at the time of bed formation and 2 weeks after bed formation) of metam potassium or the use of herbicides (sulfentrazone and s-ethyl dipropylthiocarbamate) as the supplemental application for the control of purple nutsedge (Cyperus rotundus) in strawberry (Fragaria $\times$ ananassa) fields. Efficacy of modified Florida 3-way was not significantly different from standard Florida 3-way; however, supplemental herbicide such as s-ethyl dipropylthiocarbamate and sulfentrazone provided better purple nutsedge control than supplemental metam potassium application in one of two experimental growing seasons. Addition of metam potassium to the chloropicrin $35 \%+1,3$-dichloropropene $65 \%$ did not result in additional purple nutsedge control in Florida 3-way, which indicates the limitations of this approach.

S trawberry (Fragaria $\times$ ananassa) is a high-value crop grown on 10,000 acres in Florida with a production value of $\$ 282$ million (U.S. Department of Agriculture, National Agricultural Statistics Service, 2018). Florida is the second largest strawberry producer in the United States after California. Methyl bromide (MB) was the most widely used fumigant in Florida strawberry production before it started to phase out in 2005 due to its ozone depletion potential. MB moved readily through the soil and provided excellent control of diseases, weeds, and nematodes (Duniway, 2007). None of the commercially fumigants available today

Received for publication 14 Jan. 2020. Accepted for publication 27 Mar. 2020

Published online 14 May 2020.

${ }^{1}$ Gulf Coast Research and Education Center, University of Florida, Wimauma FL 33598

${ }^{2}$ Citrus Research and Education Center, University of Florida, Lake Alfred, FL 33850

We thank AMVAC Chemical Corp. and the Florida Strawberry Growers Association for funding and Michael Sweat for his technical assistance.

N.B. is the corresponding author. E-mail: nsboyd@ ufl.edu.

This is an open access article distributed under the CC BY-NC-ND license (https://creativecommons.org/ licenses/by-nc-nd/4.0/).

https://doi.org/10.21273/HORTTECH04573-20 move as readily through the soil or control as broad a spectrum of pests.

Purple nutsedge (Cyperus rotun$d u s)$ is widespread in more than 90 tropical and subtropical countries, affecting 52 crops worldwide (Bendixen and Nandihalli, 1987). It is a troublesome weed in Florida strawberry production as well (Boyd and MacRae, 2018). If left unchecked, purple nutsedge may induce crop losses of $90 \%$ in garlic (Allium sativum), $60 \%$ in okra (Abelmoschus esculentus), $60 \%$ in carrot (Daucus carota), 50\% in tomato (Solanum lycopersicum), 40\% in cucumber (Cucumis sativus), $40 \%$ in green bean (Phaseolus vulgaris), and $35 \%$ in cabbage (Brassica oleracea var. capitata). Purple nutsedge density up to 200 plants $/ \mathrm{m}^{2}$ is directly proportional to the shoot dry weight and fruit yield loss in tomato and pepper (Capsicum annumm) (Morales-Payan et al., 1997; William and Warren, 1975). The ability of purple nutsedge to expand laterally, form persistent patches, and penetrate plastic mulch makes it the most troublesome weed to control in plasticulture production in the southeastern United States (Webster, 2005).

The "Florida 3-way" consists of shank application of chloropicrin $35 \%+1$,3-dichloropropene 65\% (Telone C-35; Corteva Agriscience, Wilmington, $\mathrm{DE}$ ) or $60 \%$ chloropicrin $+40 \%$ 1,3-dichloropropene (Pic-Clor60; TrisEst Ag Group, Tifton, US) followed by a minicoulter application of metam sodium (metam-Na) or metam potassium (metam-K) (Noling and Cody, 2012). This is the modified version of the "Georgia 3-way" in which 1,3dichloropropene is placed 30 to $37 \mathrm{~cm}$ deep, and chloropicrin is applied 20 to $25 \mathrm{~cm}$ deep from the bed top followed by bed compression. Metam-K or metam-Na is applied immediately using a minicoulter or shanks at $10-\mathrm{cm}$ depth, and beds are recompressed (Culpepper, 2007). These "3-way" approaches often provide similar levels of broad-spectrum pest control as $\mathrm{MB}$, and the associated cost is significantly lower (MacRae, 2010).

The fumigation approach for purple nutsedge control in Florida is the combination of different fumigants such as 1,3-dichloropropene + chloropicrin; dimethyl disulphide (DMDS) + chloropicrin; and DMDS + metam-Na or metam-K (Boyd et al., 2017). Chloropicrin 35\% + 1,3-dichloropropene $65 \%$ is the one of the widely used industry standard fumigants for strawberry growers in Florida. This fumigant targets nematodes and soilborne diseases but does not have an herbicidal effect (Minuto et al., 2006). A supplemental application of metam-K using a minicoulter or

\begin{tabular}{llll}
$\begin{array}{l}\text { Units } \\
\begin{array}{l}\text { To convert U.S. to SI, } \\
\text { multiply by }\end{array}\end{array}$ & U.S. unit & SI unit & $\begin{array}{l}\text { To convert SI to U.S., } \\
\text { multiply by }\end{array}$ \\
\hline 0.4047 & acre $(\mathrm{s})$ & $\mathrm{ha}$ & 2.4711 \\
0.0731 & $\mathrm{fl} \mathrm{oz} / \mathrm{acre}$ & $\mathrm{L} \cdot \mathrm{ha}^{-1}$ & 13.6840 \\
0.3048 & $\mathrm{ft}$ & $\mathrm{m}$ & 3.2808 \\
0.0929 & $\mathrm{ft}^{2}$ & $\mathrm{~m}^{2}$ & 10.7639 \\
3.7854 & $\mathrm{gal}$ & $\mathrm{L}$ & 0.2642 \\
9.3540 & $\mathrm{gal} / \mathrm{acre}$ & $\mathrm{L} \cdot \mathrm{ha}^{-1}$ & 0.1069 \\
2.54 & inch(es) & $\mathrm{cm}$ & 0.3937 \\
1.1209 & $\mathrm{lb} / \mathrm{acre}$ & $\mathrm{kg} \cdot \mathrm{ha}^{-1}$ & 0.8922 \\
6.8948 & $\mathrm{psi}$ & $\mathrm{kPa}$ & 0.1450
\end{tabular}


drip tape injection in addition to chloropicrin $35 \%+1,3$-dichloropropene $65 \%$ may improve purple nutsedge control (Santos and Gilreath, 2007). A minicoulter consists of multiple coulters spaced $10 \mathrm{~cm}$ apart in staggered rows and places the metam$\mathrm{K}$ at $10 \mathrm{~cm}$ deep. Metam fumigants have limited horizontal movement and higher downward movement, particularly with the use of single drip tape in sandy soil (Ou et al., 2006). This is attributed to the low vapor pressure of metam-K, which determines the capacity of metam- $\mathrm{K}$ to move in the soil. Multiple injection points improve metam distribution across the bed top, and the shallow injection depth places it where most of the weed seeds and tubers occur (Dittmar et al., 2018). This technology enhances distribution across the bed top and does not require additional water for application. Metam- $\mathrm{K}$ is more typically applied via injections into the drip irrigation system which can result in poor distribution but does not require the purchase of new application technology, reduces worker exposure to the fumigant (Ajwa et al., 2002), and provides flexibility to the growers in terms of application timings.

There are limited herbicide options available for purple nutsedge control in strawberry. S-ethyl dipropylthiocarbamate (EPTC) applied at $2.91 \mathrm{~kg} \cdot \mathrm{ha}^{-1}$ can provide up to $74 \%$ control of purple nutsedge (Reed et al., 2016), whereas sulfentrazone applied pre- or postemergence provides $>75 \%$ purple nutsedge control at 0.11 to $0.28 \mathrm{~kg} \cdot \mathrm{ha}^{-1}$ (Grichar et al., 2003). These herbicides could be a component of an integrated weed management program, replacing supplemental metam-K. Replacement of metam-K with herbicides would lower input costs, and distribution is typically not an issue.

The major objectives of this project were to compare the effect of 1 ) supplemental metam-K application using a 14-disk minicoulter vs. drip tape injection, 2) different timings of supplemental metam- $\mathrm{K}$ application, and 3 ) different supplemental herbicides vs. metam-K applications for purple nutsedge control in strawberry fields.

\section{Materials and methods}

Field trials were conducted at the University of Florida Gulf Coast Research and Education Center in Wimauma (lat. $27.76^{\circ} \mathrm{N}$, long. $82.23^{\circ} \mathrm{W}$ ) during the $2016-17$, 2017-18, and 2018-19 strawberry production seasons. The soil type at the experimental site is a Myakka fine sand (Siliceous Hypothermic Oxyaquic Alorthod) slightly acidic $(\mathrm{pH}$ 6.5-6.8), and low in organic matter (0.9\% to $1.2 \%)$.

Field preparation included disc cultivation and leveling, followed by bed formation using a bed press. Bed dimensions were 4 - $\mathrm{ft}$ center-to-center spacing, 28 inches wide at the top, and 12 inches tall. The plot length was 50 - $\mathrm{ft}$ linear bed length. All plots were treated with chloropicrin $35 \%+$ 1,3-dichloropropene $65 \%$ as a primary bed fumigant at $300 \mathrm{lb} /$ acre using a two-shank fumigation rig at 8 -inch depth in the bed. Primary bed fumigant was the fumigant used at the time of bed formation. Chloropicrin $35 \%+1,3$-dichloropropene $65 \%$ was used to suppress the soilborne pathogen and nematodes with the limited control of purple nutsedge (Minuto et al., 2006). The bed formation and primary fumigation occurred on 10 , 20, and 17 Sept. for the 2016-17, 2017-18, and 2018-19 production seasons, respectively.

The field was subdivided into four blocks based on the anticipated soil moisture level during the production season. Treatments were then arbitrarily assigned to each block. In 2016-17, $60 \mathrm{gal} / \mathrm{acre}$ metam-K [potassium N-methyldithiocarbamate $54 \%$ (K-PAM HL; AMVAC Chemical Corp., Newport Beach, CA)] was applied l) using a minicoulter at the time of bed formation, 2) through the drip tape within $24 \mathrm{~h}$ after bed formation and plastic application, and 3) through the drip tape 2 weeks after bed formation (WAB). In the 2017-18 and 2018-19 production season, two additional herbicide treatments were added including 4) $4 \mathrm{fl} \mathrm{oz} /$ acre sulfentrazone [sulfentrazone $40 \%$ (Spar$\tan$ 4F; FMC Corp., Philadelphia, PA)] and 5) $32 \mathrm{fl} \mathrm{oz} /$ acre EPTC [S-ethyl dipropylthiocarbamate $88 \%$ (Eptam 7E; Gowan Co., Yuma, AZ) over the bed top using carbon dioxide pressurized backpack sprayer immediately before laying plastic. The backpack sprayer was calibrated to deliver $0.78 \mathrm{~L} \cdot \mathrm{min}^{-1}$ and was equipped with a single flat-fan nozzle (8002VS; Teejet Spraying Systems
Co., Glendale Heights, IL) at 35 psi. Beds were covered with virtually impermeable film (Blockade; Berry Plastics, Evansville, IN) with a single drip tape (Chapin drip tape-BTF; Jain Irrigation, Haines City, FL) buried 1 inch deep at the center of the bed. All experiments included a control that was only fumigated with chloropicrin $35 \%+1,3$-dichloropropene $65 \%$ at the time of bed formation that was expected to kill soilborne pathogens and nematodes but not the purple nutsedge. Soil moisture content at the time of treatment application ranged from $15 \%$ to $20 \%$ water by volume.

'Florida Radiance' strawberry transplants were planted in the middle 15 -ft area of $50-\mathrm{ft}$-long plot. The plants were placed in two rows per bed with 14 inches between rows and plant-to-plant spacing of 16 inches at 3 to $4 \mathrm{WAB}$. Planting occurred on 5, 18 , and 15 Oct. for the 2016-17, 2017-18, 2018-19 strawberry seasons, respectively. Purple nutsedge shoots that penetrated the plastic mulch were counted in the transplanted area 5,10 , and $20 \mathrm{WAB}$ using a $0.3 \times 0.3-\mathrm{m}$ quadrat. Marketable fruit was harvested two times per week starting from late December to mid-February.

The PROC GLIMMIX procedure was used to determine the effect of treatments on purple nutsedge population density and strawberry yield in SAS (version 9.2; SAS Institute, Cary, NC). Block was treated as a random effect and the treatment as a fixed effect. Repeatedmeasure analysis was used for the purple nutsedge population density and fruit yield, which were collected at multiple times. Purple nutsedge population density data were transformed using the lognormal distribution function in the model statement; however, means presented in Table 1 are the back-transformed means. Tukey's procedure was used to separate means whenever appropriate.

\section{Results and discussion}

The treatment by date interaction for purple nutsedge was not significant in 2015-16 $(P=0.99)$ and 2016-17 $(P=0.56)$ but was significant in $2017-18(P=0.01)$. Therefore, purple nutsedge population densities are presented separately 
Table 1. Effect of different supplemental metam potassium (metam-K) fumigation application techniques and herbicides in purple nutsedge population density in the strawberry field trials conducted at Wimauma, FL, in 2016-17, 2017-18, and 2018-19 production seasons.

\begin{tabular}{|c|c|c|c|c|c|c|c|c|c|c|c|c|}
\hline \multirow[b]{4}{*}{ Treatment $^{\mathrm{z}}$} & \multicolumn{9}{|c|}{ Purple nutsedge density (plants $\left./ \mathrm{m}^{2}\right)^{\mathrm{y}}$} & & & \\
\hline & \multicolumn{3}{|c|}{$2016-17$} & \multicolumn{3}{|c|}{$2017-18$} & \multicolumn{3}{|c|}{$2018-19$} & \multirow{2}{*}{\multicolumn{3}{|c|}{ Strawberry yield $\left(\mathrm{kg} \cdot \mathrm{ha}^{-1}\right)^{\mathrm{y}}$}} \\
\hline & 5 & 10 & 20 & 5 & 10 & 20 & 5 & 10 & 20 & & & \\
\hline & WAB & WAB & WAB & WAB & WAB & WAB & WAB & WAB & WAB & $2016-17$ & $2017-18$ & $2018-19$ \\
\hline $\begin{array}{l}(35 \% \text { pic }+65 \% 1,3- \\
\text { D) (NTC) }\end{array}$ & 1 & 5 & 147 & 1 & 117 & 108 & 19 & 70 & $121 a^{x}$ & 18,164 & 16,255 & 9,547 \\
\hline $\begin{array}{c}(35 \% \text { pic }+65 \% 1,3- \\
\text { D) }+ \text { metam }-\mathrm{K} \\
\text { with minicoulter }\end{array}$ & 3 & 6 & 163 & 3 & 109 & 133 & 6 & 74 & $92 \mathrm{a}$ & 18,610 & 16,012 & 8,486 \\
\hline $\begin{array}{l}(35 \% \text { pic }+65 \% 1,3- \\
\text { D })+ \text { metam }-K \\
(\text { drip })\end{array}$ & 1 & 6 & 137 & 1 & 87 & 122 & 14 & 21 & $28 \mathrm{~b}$ & 16,284 & 16396 & 9,517 \\
\hline $\begin{array}{l}(35 \% \text { pic }+65 \% 1,3- \\
\text { D) + metam-K } \\
\text { (drip) }\end{array}$ & 0 & 3 & 131 & 1 & 51 & 90 & 2 & 69 & $118 \mathrm{a}$ & 17,846 & 17,713 & 10,188 \\
\hline $\begin{array}{l}(35 \% \text { pic }+65 \% 1,3- \\
\text { D) + sulfentrazone }\end{array}$ & NA & NA & NA & 2 & 67 & 77 & 15 & 38 & $52 \mathrm{~b}$ & NA & 17,038 & 9,672 \\
\hline $\begin{array}{c}(35 \% \mathrm{pic}+65 \% 1,3- \\
\mathrm{D})+\mathrm{EPTC}\end{array}$ & NA & NA & NA & 0 & 98 & 63 & 8 & 13 & $23 \mathrm{~b}$ & NA & 18,250 & 12,993 \\
\hline F value & 3.52 & 0.99 & 0.09 & 1.10 & 0.26 & 0.40 & 0.85 & 2.18 & 5.35 & 0.3 & 0.4 & 0.26 \\
\hline$P$ value & 0.06 & 0.44 & 0.96 & 0.40 & 0.90 & 0.84 & 0.50 & 0.11 & 0.005 & 0.83 & 0.84 & 0.93 \\
\hline
\end{tabular}

for each weed assessment date for all years. Supplemental fumigants and herbicides did not affect $(P>0.05)$ purple nutsedge population density in any of the three production seasons compared with the control except at the final weed assessment at $20 \mathrm{WAB}$ ( $P=0.005)$ in the $2018-19$ production season. Supplemental herbicide applications had the lowest purple nutsedge population density $(<80 /$ $\mathrm{m}^{2}$ ) at $20 \mathrm{WAB}$ in 2017-18, but the difference was not significant (Table 1).

In 2018-19, herbicides EPTC and sulfentrazone consistently had a significantly lower number of purple nutsedge than other treatments at 20 WAB (Table 1). This indicates that preemergence herbicides in conjunction with fumigants may be a more effective option than the Florida 3way. Previous research found similar trends. For example, incorporation of herbicides such as pebulate, $S$-metolachlor, and napropamide in addition to chloropicrin $17 \%+1,3$-dichloropropene $83 \%$ (Telone C-17, Corteva Agriscience) showed significant purple nutsedge control in a field trial (Gilreath et al., 2004) compared with chloropicrin $17 \%+1,3$-dichloropropene $83 \%$ alone. In our study, supplemental metam-K was beneficial in only one of three production seasons. We are uncertain why seasons varied because all three seasons were comparatively similar in terms of soil moisture, rainfall, and temperature. The results are similar to those of Boyd et al. (2017) where supplemental metam-K did not provide additional benefit in terms of purple nutsedge control and tomato yield when 1,3-dichloropropene + chloropicrin was used as the primary bed fumigant. Furthermore, sequential application of metam fumigant and chloropicrin $35 \%+1,3$-dichloropropene $65 \%$ did not result in a synergistic effect for weed control or higher berry yield in California strawberry fields (Fennimore et al., 2003; Trout and Ajwa, 1999).

Lack of efficacy of our supplemental treatments observed in these experiments may be due to the prolific reproductive capacity of purple nutsedge and high nutsedge density $\left(>100 / \mathrm{m}^{2}\right)$ in the experimental sites. Additionally, one tuber can produce up to 36 plants and 332 tubers over 16 weeks and is capable of forming 6m-diameter patch containing 19,000 plants and 7000 tubers within 1 year (Anderson 1999). In this context, nontreated regions in the soil bed could result in inconsistent control and high purple nutsedge population densities over time.

Metam application timing had no effect on control levels achieved. It was hypothesized that delaying injections for 1 week would give the tubers the opportunity to sprout. Reed at al. (2016) reported that herbicides such as EPTC and fomesafen are more effective against purple nutsedge when they are applied at the tuber sprout stage. There was no significant difference between supplemental metam-K at the time of bed formation and after 2 weeks of bed formation in their effect on purple nutsedge control; however, tubers were not extracted to observe if they had sprouted at the time of application.

Effectiveness of treatments on purple nutsedge control in the experiment were based on the aboveground 
number of purple nutsedge shoots piercing through the plastic mulch; however, these numbers are affected by not only fumigation treatments but also the natural underground nutsedge tuber population existing in the experimental plot. The underground tuber population was not determined, which may be different across the experimental plots. This is one limitation when weed control is determined based on natural weed population, which was addressed by selecting the experimental sites with a history of a homogenous weed population.

None of the treatments affected $(P>0.05)$ total strawberry yield in any of the three production seasons. There was no apparent adverse effect on strawberry growth and no visual strawberry injury (data not shown).

The supplemental applications of metam-K at $390 \mathrm{~kg} \cdot \mathrm{ha}^{-1}$ after chloropicrin 35\% + 1,3-dichloropropene $65 \%$ did not improve purple nutsedge control compared with chloropicrin $35 \%+1,3$-dichloropropene $65 \%$ alone. Herbicides were also ineffective in 2 of 3 years with rates of control for sulfentrazone and EPTC at $51 \%$ and $80 \%$, respectively, in 2018 and 2019 . We conclude that the Florida 3-way and modifications of this management system did not effectively control purple nutsedge or improve strawberry yield.

\section{Literature cited}

Ajwa, H.A., T. Trout, J. Mueller, S. Wilhelm, S.D. Nelson, R. Soppe, and D. Shatley. 2002. Application of alternative fumigants through drip irrigation systems. Phytopathology 92:1349-1355.

Anderson, R.L. 1999. Cultural strategies reduce weed densities in summer annual crops. Weed Technol. 13:314-319.

Bendixen, L.E. and U.B. Nandihalli. 1987. Worldwide distribution of purple and yellow nutsedge (Cyperus rotundus and C. esculentus). Weed Technol. 1:61-65.
Boyd, N.S., G. Vallad, F. Wu, J. Noling, and Z. Guan. 2017. Placement of metam potassium in combination with dimethyl disulfide, chloropicrin, and 1,3-dichloropropene for Cyperus rotundus L. and broadleaf weed control in tomato (Solanum lycopersicum L.). Crop Prot. 100:45-50.

Boyd, N.S. and A.W. MacRae. 2018. Managing yellow and purple nutsedge in Florida strawberry fields. Univ. Florida, Inst. Food Agr. Sci. Ext., Gainesville.

Culpepper, A.S. 2007. Comparing MB alternative in acreage on farm trials. Annu. Intl. Res. Conf. Methyl Bromide Alternatives Emission Reductions 20:1-5.

Dittmar, P.J., N.S. Dufault, J. Desaeger, J.W. Noling, P. Stansly, N.S. Boyd, M.S. Paret, and S.E. Webb. 2018. Integrated pest management, p. 19-33. In: P.J. Dittmar, J.H. Freeman, M.L. Paret, and H. Smith (eds.). Vegetable production handbook. Univ. Florida, Inst. Food Agric. Sci. Ext., Gainesville.

Duniway, J.M. 2007. Status of chemical alternatives to methyl bromide for preplant fumigation of soil. Phytopathology 92:1337-1343.

Fennimore, S.A., M.J. Haar, and H.A. Ajwa. 2003. Weed control in strawberry provided in shank- and drip-applied methyl bromide alternative fumigants. HortScience 38:55-61.

Gilreath, J.P., J.P. Jones, B.M. Santos, and A.J. Overman. 2004. Soil fumigant evaluations for soilborne pest and Cyperus rotundus control in fresh market tomato. Crop Prot. 23:889-893.

Grichar, W.J., B.A. Besler, and K.D. Brewer. 2003. Purple nutsedge control and potato (Solanum tuberosum) tolerance to sulfentrazone and halosulfuron. Weed Technol. 17:485-490.

MacRae, A. 2010. Evaluation of all components of the 3 -way fumigant system in a tomato production field in central Florida. Annu. Intl. Res. Conf. Methyl Bromide Alternatives and Emission Reductions, Orlando, FL. <https://www. mbao.org/prev_year>.

Minuto, A., M.L. Gullino, F. Lamberti, T.D. Addabbo, E. Tescari, H. Ajwa, and A. Garibaldi. 2006. Application of an emulsifiable mixture of 1,3-dichloropropene and chloropicrin against root knot nematodes and soilborne fungi for greenhouse tomatoes in Italy. Crop Prot. 25:1244-1252.

Morales-Payan, J., B. Santos, W. Stall, and T. Bewick. 1997. Effects of purple nutsedge (Cyperus rotundus) on tomato (Lycopersicon esculentum) and bell pepper (Capsicum annuum) vegetative growth and fruit yield. Weed Technol. 11:672676.

Noling, J.W. and M. Cody. 2012. Large scale demonstration trialing of methyl bromide alternatives in Florida strawberries. Annu. Intl. Res. Conf. Methyl Bromide Alternatives Emission Reductions 32:1-7.

Ou, L.T., J.E. Thomas, A.L. Hartwell, J.C. Vu, and D.W. Dickson. 2006. Effect of application methods of metam sodium and plastic covers on horizontal and vertical distributions of methyl isothiocyanate in bedded field plots. Arch. Environ. Contam. Toxicol. 51:164-173.

Reed, T.V., N.S. Boyd, and P.J. Dittmar. 2016. Application timing influences purple nutsedge (Cyperus rotundus) and yellow nutsedge (Cyperus esculentus) susceptibility to EPTC and fomesafen. Weed Technol. 30:743-750.

Santos, B.M. and J.P. Gilreath. 2007. Effects of water delivery volume, rates and concentrations of metam potassium on purple nutsedge emergence in mulched beds. HortTechnology 17:191-194.

Trout, T. and H. Ajwa. 1999. Strawberry response to fumigants applied by drip irrigation systems. Annu. Intl. Res. Conf. Methyl Bromide Alternatives Emission Reductions 10:1-3.

U.S. Department of Agriculture, National Agricultural Statistics Service. 2018. <https://www.nass.usda.gov/>.

Webster, T.M. 2005. Patch expansion of purple nutsedge (Cyperus rotundus) and yellow nutsedge (Cyperus esculentus) with and without polyethylene mulch. Weed Sci. 53:839-845.

William, R.D. and G.F. Warren. 1975. Competition between purple nutsedge and vegetables. Weed Sci. 23:317-323. 